\title{
Occurrence, Prevalence, and Distribution of Viruses Infecting Peanut in Argentina
}

\author{
S. de Breuil, CONICET fellow, and M. S. Nievas and F. J. Giolitti, Instituto de Fitopatología y Fisiología Vegetal \\ (IFFIVE-INTA), Córdoba, Argentina; L. M. Giorda, Estación Experimental Agropecuaria Manfredi, Córdoba, Ar- \\ gentina; and S. L. Lenardon, IFFIVE-INTA, Córdoba, Argentina
}

\begin{abstract}
de Breuil, S., Nievas, M. S., Giolitti, F. J., Giorda, L. M., and Lenardon, S. L. 2008. Occurrence, prevalence, and distribution of viruses infecting peanut in Argentina. Plant Dis. 92:1237-1240.

This is the first survey to determine the occurrence, prevalence, and distribution of peanut (Arachis hypogaea) viral diseases in Argentina. It was conducted in the province of Córdoba, which has $92 \%$ of the country's peanut production. It included the main peanut viruses Peanut mottle virus $(\mathrm{PeMoV})$, Peanut stripe virus (PStV), Cucumber mosaic virus (CMV), Peanut stunt virus (PSV), Tomato spotted wilt virus (TSWV), and Groundnut ringspot virus (GRSV). Leaf samples from 1,028 individual peanut plants with virus-like symptoms and 986 samples from asymptomatic plants were collected in six counties of Córdoba over 3 years and serologically tested for the presence of viruses. PeMoV was the most frequently detected virus, found in 58.8, 34.2, and $23.4 \%$ of samples from the 2003-04, 2004-05, and 2005-06 growing seasons, respectively, and it was found in all sampled counties. Also, it was the only virus detected in asymptomatic plants. Less than $4 \%$ of symptomatic plants were infected with CMV or GRSV; $0.5,3.6$, and $2 \%$ of samples were positive for CMV; and 0.5, 3.1, and 1.6\% were positive for GRSV in the 2003-04, 2004-05 and 2005-06 seasons, respectively. Some mixed infections were found: CMV-PeMoV and GRSV-PeMoV. During this survey, PSV, PStV, and TSWV were not detected in any peanut samples.
\end{abstract}

Additional keywords: epidemiology, virus diseases

Argentina currently ranks second for peanut (Arachis hypogaea L.) exports worldwide, and the crop represents an important income source for farmers (1). The average cultivated area has been about 240,000 ha for the past 10 years, and most of the production is exported. The province of Córdoba, located in central Argentina, has $92 \%$ of the country's peanut-growing area and accounts for $96 \%$ of its production. Six counties in the province, Río Cuarto, Juárez Celman, Tercero Arriba, General San Martín, General Roca, and Río Segundo, are the main growing areas.

Several viruses have been reported for peanut (8) but only four of these have been identified in Argentina: the aphidtransmitted Peanut mottle virus (PeMoV; 11) and Cucumber mosaic virus (CMV; 6) and the thrip-transmitted Tomato spotted wilt virus (TSWV; 19) and Groundnut ringspot virus (GRSV; 5). Of these, CMV reached high incidence levels and reduced grain yield in some peanut fields during

Corresponding author: S. L. Lenardon

E-mail: slenard@infovia.com.ar

Accepted for publication 9 April 2008.

doi:10.1094/PDIS-92-8-1237

(C) 2008 The American Phytopathological Society the 1999-2000 and 2005-06 cropping seasons $(7,18)$.

Peanut stripe virus (PStV) and Peanut stunt virus (PSV), both transmitted by aphids in a nonpersistent manner, are two economically important seedborne peanut viruses that have been not reported in Córdoba. PStV-infected plants display a wide range of leaf symptoms depending on virus isolate, peanut cultivar, and time of infection which are hard to distinguish from those caused by other viruses infecting peanut, such as PeMoV (13). PSV causes shortening of the petioles, reduction in the size of leaflets, chlorosis, and malformation of leaf and stunting (8), similar to CMV.

Despite the economic importance of peanut crops, only limited information is available about viral disease incidence, distribution, and effects on yield. Such information is needed as the first step toward the design of effective disease management strategies. Therefore, a 3-year survey was undertaken to evaluate the occurrence, prevalence, and distribution of virus diseases naturally affecting peanut crops, including PeMoV, PStV, CMV, PSV, TSWV, and GRSV.

\section{MATERIALS AND METHODS}

Sample collection. The surveys were carried out in the province of Córdoba,
Argentina in February and March of 2004 2005, and 2006. During the 3-year study, 167 farm fields in six counties were arbitrarily selected and surveyed for virus infections. In each field, four to eight young leaf samples were randomly collected from plants showing virus-like symptoms (mosaic, mottling, chlorosis, necrosis, vein clearing or yellowing, line patterns, chlorotic ringspots, leaf deformation, and stunting). A similar number of leaf samples from asymptomatic plants were collected in each field. Each sample was placed in a plastic bag, tagged with symptom description and origin (town and county), and kept on ice and stored at $4{ }^{\circ} \mathrm{C}$ for 1 or 3 days prior to serological testing by double-antibody sandwich enzymelinked immunosorbent assay (DAS-ELISA) or dot-blot immunoassay (see below).

Disease prevalence was determined as the ratio between the number of fields where a viral disease was present and the total number of fields sampled each year (20).

Sources of antisera and positive controls. Commercial ELISA kits with specific antibodies against CMV, PSV, TSWV, and GRSV/TCSV with their respective positive controls were used (Agdia Inc., Elkhart, IN). PeMoV and PStV antisera and their positive controls were provided by Dr. W. D. Dar (ICRISAT, India).

Serological assays. DAS-ELISA. All samples were serologically tested to determine the presence of CMV, PSV, TSWV, and GRSV (4). Tissue samples (approximately $0.1 \mathrm{~g}$ ) were ground in extraction buffer $(1: 10 \mathrm{wt} / \mathrm{vol} ; 3 \mathrm{mM} \mathrm{KCl}, 3$ $\mathrm{mM} \quad \mathrm{NaN}_{3}, 8 \mathrm{mM} \mathrm{Na}_{2} \mathrm{HPO}_{4}, 1 \mathrm{mM}$ $\mathrm{NaH}_{2} \mathrm{PO}_{4}$, and $0.13 \mathrm{M} \mathrm{NaCl}$ [phosphatebuffered saline] containing $2 \%$ polyvinylpyrrolidone-40,000, and $0.05 \%$ Tween 20, pH 6.8). Virus-specific immunoglobulin Gs (IgGs) and alkaline phosphataseconjugated IgGs were used following the supplier's protocols (Agdia Inc.). After substrate was added, reactions were measured spectrophotometrically at $405 \mathrm{~nm}$ with an ELISA reader (Dynex MRX II). Samples with absorbance values greater than the mean of the healthy controls plus three times the standard deviation were considered positive.

Dot-blot immunoassay. Peanut leaf samples were tested for detection of 
PeMoV and PStV. Nitrocellulose membranes (Bio-Rad Laboratories, Richmond, CA) were soaked for $5 \mathrm{~min}$ in Trisbuffered saline (TBS; $20 \mathrm{mM}$ Tris-HCL, $0.5 \mathrm{M} \mathrm{NaCl}, \mathrm{pH} 7.4)$. Leaf samples and positive and negative controls were homogenized $(1: 10 \mathrm{wt} / \mathrm{vol})$ in extraction buffer $(0.05 \%$ Tween $20,0.01 \mathrm{M}$ diethyldithiocarbamic acid in TBS) and $25 \mu \mathrm{l}$ of each extract was dotted onto the membranes, which were immersed in blocking solution (5\% nonfat dried milk [NFDM] + $2 \%$ Triton $\mathrm{X}-100$ in TBS) with gentle shaking overnight at room temperature. After three 5-min washes in $0.05 \%$ Tween 20 in TBS (TBS-T), membranes were incubated for $2 \mathrm{~h}$ in primary antiserum (1:400 in TBS + 2\% NFDM) which had be preadsorbed with healthy plant tissue. Membranes were washed as described above and incubated with goat anti-rabbit IgG conjugated to alkaline phosphatase (Bio-Rad Laboratories) diluted 1:3,000 in TBS for $2 \mathrm{~h}$ at room temperature. Detection was performed with nitro blue tetrazolium chloride at $30 \mathrm{mg} \mathrm{ml}^{-1}$ and 4 chloro 3-indol phosphate p-toluidine at $15 \mathrm{mg} \mathrm{ml}^{-1}$ in $0.1 \mathrm{M}$ Tris, $0.1 \mathrm{M} \mathrm{NaCl}$, and $5 \mathrm{mM}$ $\mathrm{MgCl}_{2}, \mathrm{pH}$ 9.5. Membranes were incubated in substrate solution until well- defined blue dots developed on the positive controls.

Electron microscopy. Some symptomatic leaf samples positive and negative by DAS-ELISA or dot-blot were tested by leaf dip to confirm virus particle presence. Portions of symptomatic leaves were cut with a razor blade in a drop of $0.01 \mathrm{M}$ phosphate buffer, $\mathrm{pH}$ 7.2. The tissue extracts were then transferred to carboncoated copper grids (Sigma-Aldrich, St. Louis). After $10 \mathrm{~min}$, the grids were washed with distilled water, drained onto filter paper, negatively stained with uranyl acetate $2 \%$, and examined using a Jeol 1220 transmission electron microscope (Jeol, Tokyo).

\section{RESULTS}

In three growing seasons, 1,028 samples from peanut plants with virus-like symptoms and 986 samples from asymptomatic plants were assessed.

PeMoV, CMV, and GRSV were found in all cropping seasons but PStV, PSV, and TSWV were not detected by DAS-ELISA and dot-blot immunoassays, respectively.

Symptoms caused by each virus were distinct. PeMoV infection was characterized mainly by mild leaf mottling. Plants infected with CMV had severe plant stunting, malformation, and reduced leaflets with chlorotic mottling. GRSV symptoms included plant stunting, small distorted leaves with severe chlorosis, line patterns, and concentric ringspots. In mixed infections, PeMoV symptoms were masked either by CMV or GRSV.

$\mathrm{PeMoV}$ was the most frequent virus in symptomatic plants during the three growing seasons and it was the only virus detected from asymptomatic plants (Table 1). A smaller number of symptomatic samples was infected with CMV and GRSV in the 3 years (Table 1). Also, double virus infections were detected in the 2004-05 and 2005-06 seasons, with seven samples infected with both PeMoV and CMV and nine samples with PeMoV and GRSV. In all cropping seasons, a significant percentage of symptomatic samples did not react with antisera against any of the six viruses (Table 1).

Virus identity was verified by electron microscopy. Micrographs of crude sap extracted from samples showing virus symptoms of PeMoV, CMV, and GRSV and positive by serology revealed particles with morphology typical of potyviruses, cucumoviruses, and tospoviruses respectively (Fig. 1). A few symptomatic plants

Table 1. Analysis of peanut leaf samples for six viruses using double-antibody sandwich enzyme-linked immunosorbent assay and dot-blot immunoassays

\begin{tabular}{|c|c|c|c|c|c|c|c|c|c|}
\hline \multirow[b]{2}{*}{ Seasons, samples ${ }^{\mathbf{b}}$} & \multicolumn{6}{|c|}{ No. of positive samples $(\%)^{\mathrm{a}}$} & \multirow[b]{2}{*}{ Negative } & \multicolumn{2}{|c|}{ Mixed infections } \\
\hline & PeMoV & PStV & CMV & PSV & GRSV & TSWV & & PeMoV + CMV & PeMoV + GRSV \\
\hline \multicolumn{10}{|l|}{$2003-04$} \\
\hline $406 \mathrm{~S}$ & $239(58.8)$ & 0 & $2(0.5)$ & 0 & $2(0.5)$ & 0 & $163(40.1)$ & 0 & 0 \\
\hline 364 A & $30(8.2)$ & 0 & 0 & 0 & 0 & 0 & 334 (91.7) & 0 & 0 \\
\hline \multicolumn{10}{|l|}{ 2004-05 } \\
\hline $383 \mathrm{~S}$ & $133(34.7)$ & 0 & $14(3.6)$ & 0 & $12(3.1)$ & 0 & 237 (61.9) & $4(1.0)$ & $9(2.3)$ \\
\hline 363 A & $28(7.7)$ & 0 & 0 & 0 & 0 & 0 & $335(92.3)$ & 0 & 0 \\
\hline \multicolumn{10}{|l|}{ 2005-06 } \\
\hline $239 \mathrm{~S}$ & $56(23.4)$ & 0 & $5(2.0)$ & 0 & $4(1.6)$ & 0 & $177(74.0)$ & $3(1.2)$ & 0 \\
\hline $259 \mathrm{~A}$ & $22(8.5)$ & 0 & 0 & 0 & 0 & 0 & $237(91.5)$ & 0 & 0 \\
\hline
\end{tabular}

a Viruses: Peanut mottle virus (PeMoV), Peanut stripe virus (PStV), Cucumber mosaic virus (CMV), Peanut stunt virus (PSV), Groundnut ringspot virus (GRSV), and Tomato spotted wilt virus (TSWV). Percentages = positive samples/total samples.

${ }^{\mathrm{b}}$ Cropping seasons and number of samples collected; $\mathrm{S}=$ symptomatic samples and $\mathrm{A}=$ asymptomatic samples.

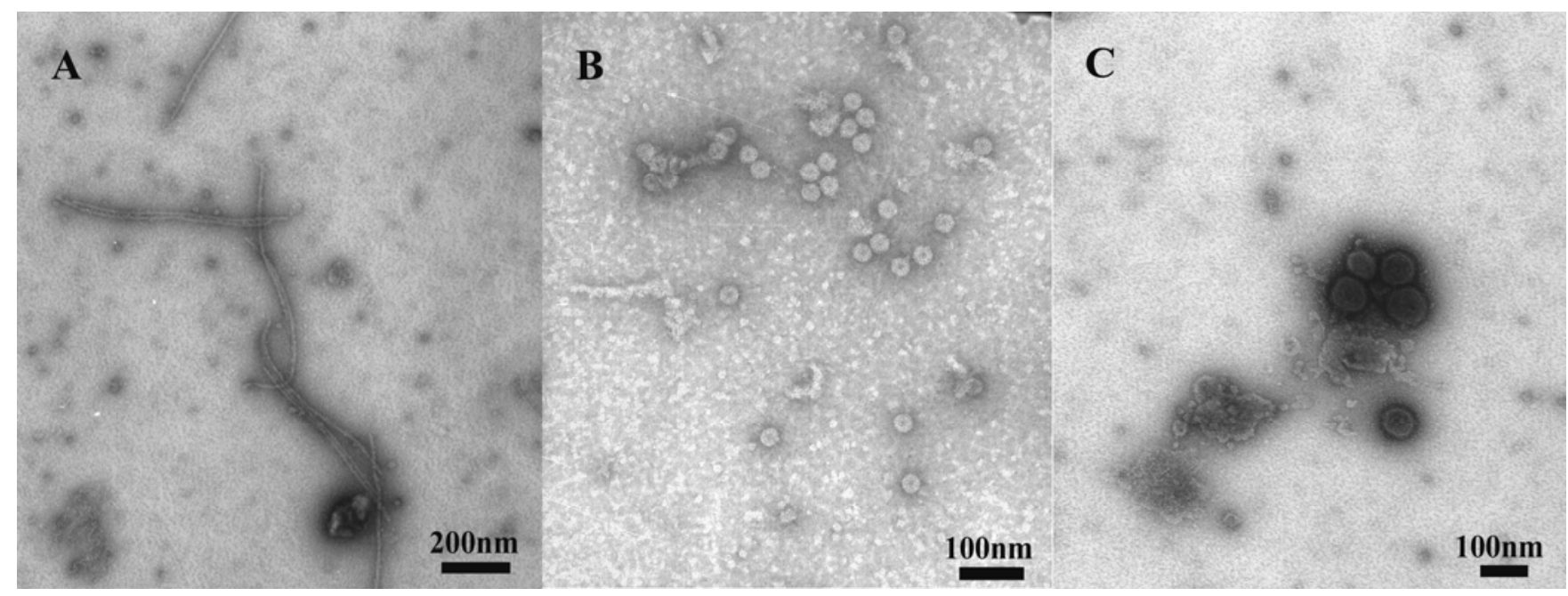

Fig. 1. Leaf-dip preparations from symptomatic peanut samples showing: A, filamentous particles typical of potyviruses tested positive to Peanut mottle virus antiserum; B, cucumovirus-like particles from a sample positive for Cucumber mosaic virus; $\mathbf{C}$, tospovirus like-particles from a Groundnut ringspot virus-positive sample. 
that were negative to serology tests showed unidentified elongated flexuous particles (data not shown).

Highest prevalence for the three viruses was found in the 2004-05 cropping season. Among the viruses, PeMoV was detected most frequently in every season (Table 2). Virus diseases were detected in all six counties and PeMoV was found in all surveyed counties in every year, whereas CMV and GRSV were more geographically restricted (Fig. 2). CMV was found in Río Cuarto, Juárez Celman, General San Martín, and General Roca counties but not in Tercero Arriba and Río Segundo. GRSV was found in all counties except for Río Cuarto and General Roca. CMV and GRSV distribution varied among years but they were found in Juárez Celman County every year. CMV occurred mostly in the central-southern part of the peanut-producing area, whereas GRSV was distributed mostly in the centralnorthern area.

\section{DISCUSSION}

This is the first report of an extensive survey carried out using serological procedures to determine the prevalence and distribution of viruses that affect peanut crops in Argentina. PeMoV, CMV, and GRSV were the only viruses detected during the 3-year study.

Symptom expression of CMV and GRSV was positively correlated with detection of these viruses by DASELISA. On the other hand, PeMoV symptoms were very mild or simply overlooked at the time of collection, as they tend to fade as plants mature (12). In addition, PeMoV symptoms are masked in mixed infections.

PeMoV was the most widespread virus and it was found in most of the peanut fields surveyed in this 3-year study, whereas CMV and GRSV occurred in fewer fields with a more limited geographical distribution. For the three viruses, highest prevalence occurred in the 2004-05 cropping season, probably because the area sown with peanut was 42,000 ha higher in this season than in the others. PeMoV prevalence in the 2003-04 and 2004-05 cropping seasons was not substantially different. In contrast, the lowest occurrence of $\mathrm{PeMoV}$ was in the 2005-06 cropping season. Average daily temperatures were particularly high that season and this could have resulted in attenuated symptom expression and, consequently, influenced sampling. In fact, the number of asymptomatic plants infected with PeMoV confirms the epidemiological importance of this virus, because apparently healthy plants can carry viruscontaminated seed (3).

Results showed that PeMoV is well established throughout the peanut production area, possibly due to substantial seed transmission, which can reach up to $8.5 \%$ in some peanut genotypes (8). This virus was first reported in peanut in Córdoba province during the 1985 season (11), and the common practice among farmers to use seed from the previous season insures the continuous presence and dissemination of PeMoV in the field.

CMV has been detected in the central and southern parts of the peanut-producing area, where disease incidence has reached $58.5 \%$ and reduced peanut yield by $30 \%$ in some peanut fields $(7,18)$. CMV may be defined as a generalist virus, which is characterized by infecting many species that often include weeds, and tends to be poorly adapted to any particular host $(9,16)$. Generalist viruses, often the most important economically, are opportunists that quickly invade and exploit new sites, and disease incidence occurs in cycles of rapid epidemic increase and decline $(9,16)$.

Traditionally, the peanut-growing area was concentrated in the central region of Córdoba province (Río Segundo, Tercero Arriba, General San Martín, and North Juárez Celman Counties; 17); currently, it has expanded toward the south of the province (South Juárez Celman, Río Cuarto, and General Roca; 17), where the virus was probably present in other legume crops such as alfalfa (Medicago sativa L.) and white clover (Trifolium repens L.) which are used as cattle pastures and are colonized by the CMV-transmitting aphids Aphis craccivora Koch and Myzus persicae (Sulzer) (21).

Table 2. Prevalence of viruses in the main peanut-producing area of Argentina ${ }^{\mathrm{a}}$

\begin{tabular}{lcccc}
\hline & & \multicolumn{3}{c}{ Positive fields (\%) } \\
\cline { 3 - 5 } Cropping seasons & No. of fields surveyed & PeMoV & CMV & GRSV \\
\hline $2003-04$ & 55 & 80.00 & 3.63 & 3.63 \\
$2004-05$ & 56 & 85.71 & 7.14 & 10.71 \\
$2005-06$ & 56 & 48.21 & 5.35 & 7.14 \\
\hline
\end{tabular}

a Viruses: Peanut mottle virus (PeMoV), Cucumber mosaic virus (CMV), and Groundnut ringspot virus (GRSV).

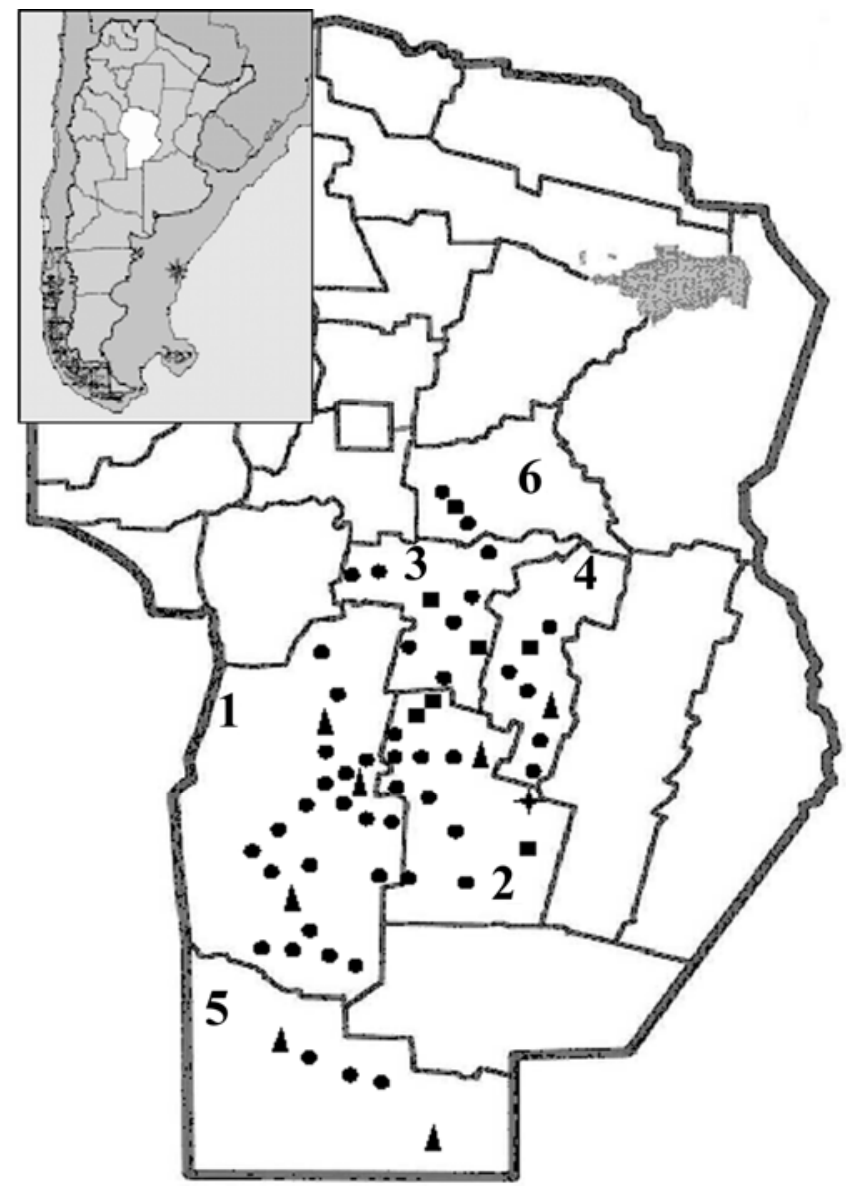

Fig. 2. Córdoba province map showing virus distribution of the three viruses found infecting peanut crops during the seasons 2003-04, 2004-05, and 2005-06, in six counties: 1, Río Cuarto; 2, Juárez Celman; 3, Tercero Arriba; 4, General San Martín; 5, General Roca; and 6, Río Segundo. Inset: Argentina map showing the Córdoba province. The presence of viruses in a given county is indicated by $\mathbf{0}=$ Peanut mottle virus $(\mathrm{PeMoV}) ; \boldsymbol{\Delta}=\mathrm{PeMoV}+$ Cucumber mosaic virus; $\mathbf{\square}=\mathrm{PeMoV}+$ Groundnut ringspot virus; and $\checkmark=$ the three viruses present. 
Seedborne viruses, such as CMV and PeMoV, have a great epidemiological importance because they spread by infected seed. Then, peanut plants from those seeds, plus volunteer plants that come from infected seed from the previous cropping season, serve as primary sources of inoculum for other plants. Extensive surveys to determine seedborne virus occurrence in different regions are required to define areas with different risk profiles for economic losses and are the first step to define threshold levels of seedborne infection for areas (15). Furthermore, seed contamination could be a limiting factor in breeding and selection programs because infected seed stocks may carry the viruses. In addition, these viruses could be dispersed through peanut germplasm exchange. The use of certified virus-free seed is a preventive practice that should be considered, because several methods for testing seedborne viruses in peanut are available $(2,10,14)$.

GRSV, which is not seed transmitted, was distributed mostly in the centralnorthern area of the peanut-growing region in Córdoba. Its geographical distribution might be related to the presence of host reservoirs and thrip vectors populations. In Argentina, there is no information about the presence and transmission efficiency of thrip vectors in peanut crops.

In the present survey, PStV, PSV, and TSWV were not detected. Although TSWV was reported in peanut in Río Segundo County during the 1985 crop season (19), GRSV antisera were not used at that time, and infections by this related Tospovirus sp. cannot be ruled out. The lack of virus detection in samples expressing virus-like symptoms might be due to low virus concentration, unidentified viruses, or others causes such as insect toxemia, herbicide injury, or nutritional deficiency that may induce symptoms similar to those caused by viruses (22).

This survey of peanut fields in Córdoba, Argentina showed that viral diseases such as PeMoV, CMV, and GRSV are of special concern for the peanut industry. Thus, research is currently focused on epidemiology, yield loss assessment, and management strategies of these viruses.

\section{ACKNOWLEDGMENTS}

This work has been made possible by the financial support of Fundación Maní Argentino, SecytUniversidad Nacional de Río Cuarto, and PNIND 2251 and PNIND 2252 INTA projects. We thank W. D. Dar, International Crops Research Institute for the Semi-Arid Tropics (ICRISAT), India, for the kind supply of PeMoV and PStV antisera and their respective positive controls; and E. Taleisnik for checking the language. S. de Breuil has a fellowship of Consejo Nacional de Investigaciones Científicas y Técnicas (CONICET).

\section{LITERATURE CITED}

1. Ackermann, B. 2006. Maní argentino: oportunidades y desafíos. Pages 48-50 in: XXI Jornada Nacional de Maní, General Cabrera, Córdoba, Argentina.

2. Bharathan, N., Reddy, D. V. R., Rajeshwari, R., Murthy, V. K., Rao V. R., and Lister R. M. 1984. Screening peanut germplasm lines by enzyme-linked immunosorbent assay for seed transmission of peanut mottle virus. Plant Dis. 68:757-758.

3. Bock, K. R., and Kuhn, C. W. 1975. Peanut mottle virus. $\mathrm{CMI} / \mathrm{AAB}$ Descriptions of Plant Viruses, No. 141. Commonw. Mycol. Inst./ Assoc. Appl. Biol. Kew, England.

4. Clark, M. F., and Adams, A. N. 1977. Characteristics of the microplate method of enzymelinked immunosorbent assay for the detection of plant viruses. J. Gen. Virol. 34:475-483.

5. de Breuil, S., Abad, J., Nome, C. F., Giolitti, F., López Lambertini, P., and Lenardon, S. 2007. Groundnut ringspot virus: an emerging Tospovirus inducing disease in peanut crops. J. Phytopathol. 155:251-254.

6. de Breuil, S., Giolitti, F., and Lenardon, S. 2005. Detection of Cucumber mosaic virus on peanut (Arachis hypogaea L.) in Argentina. J. Phytopathol. 153:722-725.

7. de Breuil, S., Moresi, A., and Lenardon, S. 2006. Nueva epidemia de Cucumber mosaic virus. Pages 24-25 in: XXI Jornada Nacional de Maní, General Cabrera, Córdoba, Argentina.

8. Demski, J. W., and Reddy, D. V. R. 1997. Diseases caused by viruses. Pages 53-59 in: Compendium of Peanut Diseases, Second Edition. N. Kokalis-Burelle, D. M. Porter, R. Rodríguez-Kábana, D. H. Smith, and P. Subrahmanyam, eds. American Phytopathological Society Press, St. Paul, MN.

9. Gallitelli, D. 2000. The ecology of Cucumber mosaic virus and sustainable agriculture. Virus Res. 71:9-21.

10. Gillaspie, A. G., Jr., Pittman, R. N., Pinnow, D. L, and Cassidy, B. G. 2000. Sensitive methods for testing peanut seed lots for Peanut stripe and Peanut mottle viruses by immunocapturereverse transcription-polymerase chain reaction. Plant Dis. 84:559-561.

11. Giorda, L. M., Nome, S. F., and Laguna, I. G. 1985. El virus del moteado del maní en la Argentina. IDIA No. 433-436:53-57.

12. Gudauskas, R. T., Burch, K. B., Jin, P., Hagan, A. K., and Weeks, J. R. 1993. Identification of viruses infecting peanut in Alabama. Peanut Sci. 20:71-73.

13. Higgins, C. M., Dietzgen, R. G., Mat Akin, H., Sudarsono, Chen, K., and Xu, Z. 1999. Biological and molecular variability of Peanut stripe potyvirus. Curr. Top. Virol. 1:1-26.

14. Hobbs, H. A., Reddy, D. V. R., Rajeshwari, R., and Reddy, A. S. 1987. Use of direct antigen coating and protein A coating ELISA procedures for detection of three peanut viruses. Plant Dis. 71:747-749.

15. Jones, R. A. C. 2000. Determining 'threshold' levels for seed-borne virus infection in seed stocks. Virus Res. 71:171-183.

16. Jones, R. A. C. 2004. Using epidemiological information to develop effective integrated virus disease management strategies. Virus Res. 100:5-30.

17. March, G. J., and Marinelli, A. D. 2005. Enfermedades y Sistema Productivo. Pages 1-11 in: Enfermedades del Maní en Argentina, Primera Edición. G. J. March and A. D. Marinelli, eds. Biglia Impresores, Córdoba, Argentina.

18. March, G. J, Marinelli, A., Lenardon, S. L., Pedrozo, F., Kearney, M., Oddino, C., and Remedi, D. 2000. Incidencia, distribución espacial y pérdidas por Cucumovirus en maní. Page 34 in: XV Jornada Nacional de Maní, General Cabrera, Córdoba, Argentina.

19. Nome, S. F., Giorda, L. M., Truol de Izaurralde, G., and Laguna, I. G. 1985. Necrosis del brote del maní causada por el virus de la marchitez manchada del tomate. IDIA No. 433-436:29-33.

20. Nutter, F. W., Jr., Teng, P. S., and Shokes, F. M. 1991. Disease assessment terms and concepts. Plant Dis. 75:1187-1188.

21. Ortego, J., and Mier Durante, M. P. 2003. Acyrthosiphon (A.) loti (Hemiptera: Aphididae) hallado sobre alfalfa en la Argentina. Rev. Soc. Entomol. Argentina 62 (1-2):32-34.

22. Sherwood, J. L., and Melouk H. A. 1995. Viral diseases and their management. Pages 59-63 in: Peanut Health Management, First Edition. H. A. Melouk and F. M. Shokes, eds. American Phytopathological Society Press, St. Paul, MN. 